\title{
Struktur Komunitas Mikroartropoda Bryofauna Terestrial Di Zona Tropik Gunung Ungaran, Semarang, Jawa Tengah
}

\author{
Atik Munarsih, Rully Rahadian, Mochammad Hadi \\ Jurusan Biologi, FSM, Undip, Tembalang, Semarang 50275 Telp (024) 7474754; Fax. (024) 76480690 \\ E-mail: Langitbiru1504@gmail.com
}

\begin{abstract}
Bryofauna is all of the animal life which associated with moss. Actually, biodiversity of bryofauna have not been studied much in Indonesia. Research on community structure of terrestrial microarthropod bryofauna has been done in three different altitudes in the tropical zone of the Ungaran Mountain, Semarang, Central Java. The objective of this study is to compare community structure of bryofauna contained in three different altitudes in the tropical zone. The research was conducted from April to November 2012. Sampling was carried out at 3 stations with the different heights that are the station I with an altitude $750 \mathrm{~m}$ asl, the altitude of the station II with an altitude $980 \mathrm{~m}$ asl and the station III with an altitude of $1100 \mathrm{~m}$ asl. Sampling was done purposively using square plot method. Bryofauna identification was conducted in Ecology and Biosistematics Laboratory University of Diponegoro and Entomologi Laboratory of Zoology Departement Indonesian Institute of Sciences. The results shows that the tropical zone have5 classes, 16 orders and 31 suborders/family of bryofauna. Mesostigmata and Oribatida was the dominant taxa at all heights except at an altitude of $980 \mathrm{~m}$ asl, Oribatida was categorized as subdominant. Diversity of bryofauna at different heights shows that decreasing diversity patterns, along with the increasing altitude. In general, the distribution of bryofauna at different heights is quite spread evenly with the flattening index values betweens 0.84 to 0.94 . Bryofauna taxsa richness and diversity of bryophytes at different heights in the tropical zone showed the same pattern fluctuated. Taxa group which play a role as predator are taxa that the most abundant in the tropical zone of the Ungaran Mount.
\end{abstract}

Keywords:Bryofauna terrestrial, bryophytes, Ungaran mount, community structure

\begin{abstract}
Abstrak
Bryofauna merupakan fauna yang berasosiasi dengan tumbuhan lumut yang keanekaragaman hayatinya belum banyak diteliti khususnya di Indonesia. Penelitian tentang struktur komunitas mikroartropoda bryofauna terestrial telah dilakukan di tiga ketinggian berbeda di zona tropik gunung Ungaran, Semarang, Jawa Tengah pada bulan April-November 2012. Penelitian ini bertujuan untuk membandingkan struktur komunitas bryofauna pada tiga ketinggian berbeda. Pengambilan sampel dilakukan di 3 stasiun yaitu stasiun I dengan ketinggian 750 mdpl, stasiun II dengan ketinggian $980 \mathrm{mdpl}$ dan stasiun III dengan ketinggian $1100 \mathrm{~m}$ dpl. Pengambilan sampel dilakukan secara purposive dengan metode plot kuadrat. Identifikasi bryofauna dilakukan di Laboratorium Ekologi dan Biosistematika Universitas Diponegoro dan Laboratorium Entomologi Bidang Zoologi LIPI. Hasil penelitian didapatkan 5 kelas, 16 ordo dan 31 subordo/famili mikroartropoda bryofauna terestrial. Mesostigmata dan Oribatida merupakan taksa yang dominan di semua ketinggian kecuali pada ketinggian $980 \mathrm{~m}$ dpl dimana Oribatida termasuk subdominan. Keanekaragaman mikroartropoda bryofauna terestrial pada ketinggian yang berbeda menunjukan pola keanekaragaman semakin menurun, seiring dengan semakin naiknya ketinggian tempat. Secara umum distribusi mikroartropoda bryofauna terestrial pada ketinggian yang berbeda cukup merata dengan nilai indeks perataan antara 0,84-0,94. Kekayaan taksa mikroartropoda bryofauna terestrial dan keanekaragaman jenis bryophytes pada ketinggian yang berbeda menunjukkan kesamaan pola yang bersifat fluktuatif. Kelompok taksa predator merupakan taksa yang memiliki prosentase tertinggi di zona tropik Gunung ungaran.
\end{abstract}

Kata kunci :Bryofauna terestrial, bryophytes, Gunung Ungaran, struktur komunitas 


\section{PENDAHULUAN}

Bryophytes (tumbuhan lumut) merupakan komponen penting di habitat terestrial. Bryophytes dapat ditemukan menempel pada suatu substrat di sekitar badan sungai, pada permukaan kulit batang pohon yang masih hidup maupun sudah mati, permukaan batu yang keras, hingga di lapisan permukaan tanah. Bryophytes membentuk kolonisasi dan menjadi substrat bagi bryofauna karena kemampuannya menjaga kestabilan di habitat terestrial dengan memproduksi serasah, dan mampu menahan air (Bozanik, 2011).

Menurut Gerson (1969), bryophytes diketahui dapat berperan sebagai mikrohabitat yang mempengaruhi kelimpahan organisme yang mampu beradaptasi dengan baik pada kondisikondisi cuaca yang ekstrim, sehingga beberapa hewan mikroartropoda secara penuh tergantung pada kehadiran lumut tersebut di suatu ekosistem.

Mikroartropoda yang berasosiasi dengan bryophytes membentuk struktur komunitas yang distribusinya dipengaruhi oleh faktor biotik, abiotik pada habitat tersebut. Menurut Caswell (1976), suatu komunitas kurang beranekaragam jika tidak ada interaksi antara berbagai jenis. Komposisi jenis dalam komunitas mencerminkan keseimbangan dan hubungan antar jenis bryofauna karena suatu spesies dalam komunitas memiliki peranan yang berbeda.

Berdasarkan ketinggian tempat yang berbeda, zona tropik dengan ketinggian $700 \mathrm{mdpl}$ $-1000 \mathrm{~m}$ dpl sedangkan zona montana memiliki ketinggian $1300 \mathrm{mdpl}$ - $2050 \mathrm{mdpl}$ (Steenis, 2006). Zona montana dan zona tropik Gunung Ungaran memiliki tipe vegetasi hutan tropis. Bryophytes dapat hidup dengan menempati berbagai macam habitat yang tersedia di dalam zonasi hutan tropis Gunung Ungaran Jawa Tengah.

Gunung Ungaran diperkirakan memiliki keanekaragaman bryofauna yang cukup tinggi tetapi belum banyak diteliti. Oleh karena itu penelitian ini dilakukan untuk mengetahui struktur komunitas mikroartropoda bryofauna pada lumut terestrial di zona tropik seperti yang sudah dilakukan Andrew (2003). Tumbuhan lumut yang beraneka ragam juga terdapat bryofauna beranekaragam yang hidup di dalamnya dan saling berasosiasi seperti yang telah dilakukan oleh Bozanik (2011), sehingga bryofauna yang menjadi objek penelitian ini difokuskan pada mikroartropoda yang berasosiasi dengan tumbuhan lumut terestrial di zona tropik Gunung Ungaran.

\section{BAHAN DAN METODE \\ Bahan Penelitian}

Spesimen mikroartropoda bryofauna terestrial dan alkohol $96 \%$.

\section{Alat penelitian}

Meteran, gunting, patok bambu, tali rafia, corong, botol, kasa, kantong kain, label, lux meter, GPS, termometer, hygrometer, mikroskop, cawan petri, gelas benda, kamera.

\section{Pengambilan sampel}

Pengambilan sampel mikroartropoda Bryofauna terestrial dilakukan di kawasan Gunung Ungaran, Jawa Tengah pada bulan AprilNovember 2012. Penelitian dilakukan di tiga ketinggian yang berbeda. Stasiun pertama pada ketinggian $750 \mathrm{~m}$ dpl terletak di kawasan hutan Wana Wisata Gonoharjo $\left(07^{0} 08^{\prime} 960^{\prime \prime} L S-\right.$ $110^{\circ} 19^{\prime} 964^{\prime \prime B T)}$. Stasiun kedua berada di ketinggian $980 \mathrm{~m}$ dpl di kawasan hutan pinus daerah Medini $\left(07^{0} 09^{\prime} 659\right.$ 'LS - $110^{0} 20^{\prime} 014^{\prime \prime}$ 'BT) dan stasiun ketiga berada di ketinggian $1100 \mathrm{~m}$ dpl berada di kawasan perkebunan teh daerah Promasan (0709'931'LS - 110020'405”BT). Identifikasi spesies mikroartropoda bryofauna dilakukan di Laboratorium Ekologi dan Biosistematika Fakultas Sains dan Matematika Universitas Diponegoro dan Laboratorium Entomologi bidang Zoologi, Lembaga Ilmu Pengetahuan Indonesia Cibinong.

Pengambilan sampel dilakukan secara purposive karena kondisi lumut yang tidak homogen di lokasi penelitian. Pengambilan sampel bryofauna terestrial dilakukan dengan mengambil sampel lumut di tiapstasiun dengan metode plot kuadrat. Di setiap stasiun dibuat plot besar dengan ukuran $20 \mathrm{~m}$ x $20 \mathrm{~m}$ dengan tujuan untuk membatasi lokasi pengambilan sampel. Dalam plot besar tersebut kemudian dibuat plotdengan ukuran $1 \mathrm{~m} \times 1 \mathrm{~m}$ sebanyak 3 plot sebagai ulangan. Sampel diambil dari plot kecil 
berukuran 10 x $10 \mathrm{~cm}$ di dalam plot berukuran 1 mx $1 \mathrm{~m}$ sebanyak 5 plot. Sampel lumut yang sudah diambil dimasukkan ke dalam kantong kain dan diberi label serta di setiap stasiun dilakukan pengukuran faktor-faktor lingkungan seperti suhu udara, kelembaban udara dan intensitas cahaya.

\section{Ekstraksi Mikroartropoda}

Ekstraksi mikroartropoda dilakukan dengan menggunakan Tulgren Funnel yang telah dimodifikasi. Sampel lumut dimasukkan ke dalam corong yang dilapisi kasa. Di bawah corong diletakkan perangkap berupa botol yang berisi alkohol sebagai larutan fiksatif untuk mengawetkan fauna yang diekstrak. Lampu bohlam 40 watt dipasang di atas corong untuk memberi efek panas dan terang agar fauna lumut bergerak lolos ke botol beralkohol di bawahnya. Proses ekstraksi ini dilakukan selama 7 x 24 jam.

\section{Identifikasi}

Spesimen mikroartropoda bryofauna terestrial diidentifikasi menggunakan mikroskop di Laboratorium Entomologi Bidang Zoologi LIPI. Bryofauna diidentifikasi sampai tingkat subordo atau famili.

\section{Parameter}

Parameter lingkungan yang diukur meliputi faktor abiotik di lokasi penelitian yaitu suhu udara, intensitas cahaya, kelembaban udara dan ketinggian tempat.

\section{Analisis data}

Jumlah individu masing-masing taksa dianalisis dengan menghitung kelimpahan relatif, keanekaragaman (diversity index) dan indeks perataan. Formula dari analisis tersebut adalah sebagai berikut :

Indeks kelimpahan diformulasikan dengan rumus sebagai berikut:

$\mathrm{Di}=\mathrm{ni} / \mathrm{N}$ X $100 \%$

Keterangan:

Di : Indeks kelimpahan

$\mathrm{Ni}$ : Jumlah individu ke-i

$\mathrm{N}$ : Jumlah total individu seluruh taksa

Kategori dominasi ditentukan berdasarkan nilai kelimpahan relatif yang mengacu pada kategori yang ditetapkan Engelman (1978) dalam Rahadian (2009), sebagai berikut:
a. $>10 \%$
: Dominan
b. $3,2-9,9 \%$
: Sub dominan
c. $1,0-3,1 \%$
: Recedent
d. $0,32-0,99 \%$
: Subrecedent
e. $<0,32 \%$
: Sporadik

Keanekaragaman dianalisis menggunakan indeks Shannon-Wiener (H') dan indeks perataan jenis (e). Menurut Odum (1998) formula Indeks keanekaragaman Shannon-Wiener $\left(\mathrm{H}^{\prime}\right)$ adalah sebagai berikut,

Keterangan:

$$
\mathrm{H}^{\prime}=-\sum(\mathrm{ni} / \mathrm{N} \text { In ni/N) }
$$

H' : Indeks keanekaragaman taksa

ni : Jumlah individu ke-i

$\mathrm{N}$ : Jumlah total individu

In : Logaritma bilangan dasar Besarnya indeks keanekaragaman didefinisikan sebagai berikut :

Jika $\mathrm{H}^{\prime}<1$, keanekaragamannya rendah Jika $1<\mathrm{H}^{\prime}<3$, keanekaragamannya sedang Jika H'>3 , keanekaragamannya tinggi

Sebaran bryofauna ditentukan menggunakan nilai indeks perataan yang berkisar antara 0,6-0,8 (Odum, 1993). Indeks (e) diformulasikan dengan rumus berikut :

$$
\mathrm{e}=\mathrm{H}^{\prime} / \ln \mathrm{S}
$$

Keterangan:

$\mathrm{e}:$ indeks perataan

H': Indeks keanekaragaman Shannon-Wiener

$\mathrm{S}:$ Jumlah taksa

\section{HASIL DAN PEMBAHASAN}

Bryofauna yang ditemukan di ketinggian $750 \mathrm{~m}$ dpl, $980 \mathrm{~m}$ dpl dan $1100 \mathrm{~m}$ dpl di zona tropik gunung Ungaran, terdapat 5 kelas bryofauna yang terdiri terdiri dari 16 ordo dan 31 subordo/famili mikroartropoda bryofauna terestrial.

Secara umum kelimpahan mikroartropoda bryofauna terestrial di zona tropik gunung Ungaran cenderung bersifat fluktuatif, dengan kelimpahan tertinggi terdapat di ketinggian 1100 $\mathrm{m}$ dpl dan terendah pada ketinggian $980 \mathrm{~m} \mathrm{dpl}$ (Tabel 1.). Taksa Oribatida dan Mesostigmata pada semua ketinggian secara konsisten tergolong dominan. 
Berdasarkan kelimpahan bryofauna terestrial (Tabel 1.), di ketinggian $750 \mathrm{~m} \mathrm{dpl} \mathrm{dan}$ ketinggian $1100 \mathrm{~m}$ dpl Oribatida merupakan taksa dominan, namun di ketinggian $980 \mathrm{~m}$ dpl termasuk sub dominan. Melimpahnya Oribatida di ketinggian $1100 \mathrm{~m}$ dpl dimungkinkan karena tumbuhan lumutnya relatif lebih tebal jika dibandingkan dengan stasiun yang lain, sehingga mendukung untuk tempat hidup serta menyediakan sumber makanan Oribatida sebagai fungivora.

Mesostigmata di tiga ketinggian yang berbeda pada zona tropik gunung Ungaran merupakan taksa dominan diantara taksa yang lain. Mesostigmata ditemukan dominan di ketinggian $750 \mathrm{~m}$ dpl, di ketinggian $980 \mathrm{~m} \mathrm{dpl}$ dan di ketinggian $1100 \mathrm{~m}$ dpl dengan pola kelimpahannya semakin meningkat seiring dengan naiknya ketinggian tempat (Tabel 1.). Hal tersebut kemungkinan disebabkan karena tumbuhan lumut menyediakan sumber makanan dan tempat hidup bagi Mesostigmata yang seiring dengan ketinggian tempat, tumbuhan lumut semakin melimpah dan tebal.

Mesostigmata umumnya merupakan Acarina predator bagi invertebrata kecil dan berbagai macam mikroartropoda beserta telurnya. Mesostigmata selain bersifat predator juga merupakan parasit, baik secara internal atau eksternal pada hewan inang invertebrata maupun vertebrata. Mesostigmata memanfaatkan tumbuhan lumut untuk tempat berlindung dan mencari inang (Glime, 2007).

Insekta yang sedang melakukan metamorfosis atau dalam fase pupa akan menjadi inang bagi Mesostigmata. Mesostigmata memanfaatkan immobilitas Insekta saat menjadi pupa dan memparasiti tubuh inangnya untuk mendapatkan nutrisi dari tubuh inangnya.
Tabel 1. Kelimpahan taksa bryofauna mikroartropoda di zona tropik gunung Ungaran Semarang, Jawa Tengah.

\begin{tabular}{|c|c|c|c|}
\hline Stasiun & I & II & III \\
\hline Sub ordo/famili & $\mathrm{Di}$ & $\mathrm{Di}$ & $\mathrm{Di}$ \\
\hline Mesostigmata & $12,83^{*}$ & $14,32 *$ & $15,44^{*}$ \\
\hline Oribatida & $12,24 *$ & $7,16^{* *}$ & $21,85^{*}$ \\
\hline Prostigmata & $9,47 * *$ & $4,78 * *$ & $8,39 * *$ \\
\hline Aranae & $1,76^{+}$ & $0,28^{-}$ & $3,61 * *$ \\
\hline Pseudoscorpiones & $0,92^{++}$ & - & $1,81^{+}$ \\
\hline Entomobrydae & $2,60^{+}$ & $4,68 * *$ & $7,69 * *$ \\
\hline Isotomidae & $8,14 * *$ & $4,68 * *$ & $5,83 * *$ \\
\hline Neelidae & $0,67^{++}$ & - & $1,16^{+}$ \\
\hline Hipogastruridae & - & $3,30 * *$ & \\
\hline Onychiuridae & $2,35^{++}$ & $4,96 * *$ & $6,47 * *$ \\
\hline Symphypleona & $4,44 * *$ & $3,03^{+}$ & $2,80^{+}$ \\
\hline Carabidae & $3,77 * *$ & $2,30^{+}$ & $1,57^{+}$ \\
\hline (larva) & $1,01^{+}$ & - & - \\
\hline Leiodidae & $1,60^{+}$ & $5,05^{* *}$ & $0,94^{++}$ \\
\hline Nitidulidae & $4,28 * *$ & - & - \\
\hline Staphylinidae & $3,68 * *$ & - & $1,28^{+}$ \\
\hline Cecidomidae & $5,03 * *$ & $3,58 * *$ & $1,92^{+}$ \\
\hline Larva & & - & $1,11^{+}$ \\
\hline Ceratopogonidae & $4,19 * *$ & $2,11^{+}$ & $0,76^{++}$ \\
\hline Chironomidae & $1,67^{+}$ & $4,58 * *$ & - \\
\hline Psychodidae & $1,67^{+}$ & $6,51 * *$ & $2,21^{+}$ \\
\hline Sciaridae & $1,92^{+}$ & - & $2,51^{+}$ \\
\hline Dipteral larva & $1,17^{+}$ & - & - \\
\hline Aphididae & & $1,10^{+}$ & - \\
\hline Formicidae & $3,27 * *$ & $7,34 * *$ & $4,13 * *$ \\
\hline Mymaridae & $1,35^{+}$ & $2,11^{+}$ & $1,81^{+}$ \\
\hline Braconidae & $1,35^{+}$ & - & - \\
\hline Lepidoptera & $2,10^{+}$ & $2,11^{+}$ & $3,03^{+}$ \\
\hline Ectoposcidae & $1,17^{+}$ & - & - \\
\hline Trogiidae & - & - & $0,24^{-}$ \\
\hline Thysanoptera & $2,60^{+}$ & $4,58 * *$ & \\
\hline Hydroptilidae & $1,01^{+}$ & $3,85^{* *}$ & $1,81^{+}$ \\
\hline Isopoda & $1,01^{+}$ & $3.03 * *$ & $1,11^{+}$ \\
\hline Chilopoda & $0,75^{++}$ & $4,13 * *$ & $0,52^{++}$ \\
\hline
\end{tabular}

Keterangan: (*) dominan, (**) subdominan, (+) reseden, (++) subreseden, (-) sporadik

Kekayaan taksa dapat menunjukkan komposisi jumlah taksa bryofauna, pada tiga ketinggian yang berbeda di zona tropik gunung Ungaran.Hasil penelitian menunjukkan kekayaan taksa yang tertinggi berada di ketinggian $750 \mathrm{~m}$ dpl dan terendah di $980 \mathrm{~m}$ dpl (Tabel 2.). Pola kekayaan taksa bryofauna menunjukkan adanya kesamaan dengan pola keanekaragaman jenis bryophytes di tiap ketinggian (Tabel 2.). 
Tabel 2. Kekayaan, keanekaragaman, perataan taksa mikroartropoda bryofauna terestrial dan jumlah jenis bryophytes di ketinggian yang berbeda.

\begin{tabular}{lccc}
\hline Stasiun & I & II & III \\
\hline Kekayaan taksa bryofauna & 30 & 23 & 25 \\
Keanekaragaman bryofauna & & & \\
(Shannon-Wiener) & 2.99 & 2.96 & 2.69 \\
Perataan bryofauna & 0.88 & 0.94 & 0.84 \\
Jumlah jenis bryophytes & 26 & 17 & 25 \\
\hline
\end{tabular}

Struktur komunitas ditinjau dari indeks keanekaragaman dan indeks perataan (Tabel 2.), masing-masing stasiun menunjukkan hubungan antara keanekaragaman taksa dan jumlah taksa yang menyusun komunitas. Keanekaragaman bryofauna di ketinggian $750 \mathrm{~m}$ dpl cenderung menunjukkan indeks keanekaragaman yang lebih tinggi (Tabel 2.), dibandingkan dengan ketinggian lainnya. Keanekaragaman yang tinggi di ketinggian $750 \mathrm{~m}$ dpl ini kemungkinan disebabkan karena keberadaan bryofauna pada lumut yang membentuk interaksi dalam komunitas tersebut. Sebaliknya indeks keanekaragaman di ketinggian $1100 \mathrm{~m}$ dpl merupakan yang terkecil tetapi kelimpahan taksanya paling tinggi.

Hal tersebut kemungkinan disebabkan karena adanya taksa dominan yang tinggi dan menekan jumlah populasi-populasi taksa yang lain sehingga dapat menurunkan keanekaragaman. Menurut Chapin dkk (2000), hilangnya suatu spesies dapat menimbulkan pengaruh bagi anggota spesies lain di dalam komunitasnya seperti halnya musuh alaminya menjadi melimpah populasinya dan mempengaruhi keseimbangan komunitas tersebut. Keanekaragaman mikroartropoda bryofauna terestrial seiring tempat yang semakin tinggi menunjukkan pola keanekaragaman yang semakin menurun. Hal tersebut terlihat dari nilainilai indeks keanekaragaman yang semakin kecil pada tiap lokasi yang semakin tinggi (Tabel 2.). Hal tersebut dipengaruhi oleh bryophytes yang menjadi habitat, serta ketersediaan nutrisi dan faktor biologi dalam kumunitas itu sendiri baik pemangasaan maupun kompetisi. Menurut Odum (1993), keanekaragaman yang tinggi dapat ditentukan oleh tingkat kelimpahan dan perataan, apabila kelimpahan tinggi sedangkan tingkat perataan rendah maka menurunkan keanekaragaman, walaupun jumlah jenisnya banyak tetapi jika sebaran tidak merata maka nilai keanekaragamannya rendah.

Keanekaragaman mikroartropoda di ketinggian $750 \mathrm{~m}$ dpl ke ketinggian $980 \mathrm{~m}$ dpl mengalami penurunan yang tidak terlalu berarti sedang di ketinggian $1100 \quad \mathrm{~m} \quad \mathrm{dpl}$ keanekaragamannya menurun dan menjadi paling rendah (Tabel 2.). Hasil penelitian di tiga ketinggian di zona tropik tersebut masih termasuk dalam kategori keanekaragaman sedang, karena indeks keanekaragaman berkisar pada kategori $1<\mathrm{H}^{\prime}<3$.

Indeks perataan taksa bryofauna mengalami kenaikan dari ketinggian $750 \mathrm{~m} \mathrm{dpl}$ keketinggian $980 \mathrm{~m}$ dpl, kemudian pada ketinggian $1100 \mathrm{~m}$ dpl mengalami penurunan (Tabel 2.). Perataan yang tinggi di ketinggian 980 $\mathrm{m}$ dpl tersebut kemungkinkan disebabkan keanekaragaman cukup tinggi dan taksa-taksa bryofauna di ketinggian ini sebagian besar tergolong subdominan (Tabel 1.), sehingga sebarannya merata dan menunjukan keseimbangan. Menurut Odum (1993) sebaran fauna seimbang atau merata apabila mempunyai nilai indeks perataan jenis yang berkisar antara $0,6-0,8$. Indeks perataan di ketinggian $750 \mathrm{~m} \mathrm{dpl}$ dan di ketinggian $1100 \mathrm{~m}$ dpl memiliki kesamaan yaitu termasuk dalam kategori sebaran merata sehingga masih dikatakan dalam sebaran seimbang.

Hasil penelitian dapat dikatakan bahwa meskipun Mesostigmata dan Oribatida dominan pada tiap ketinggian tetapi tidak menimbulkan tekanan terhadap populasi taksa lain sehingga persebarannya merata. Perataan bryofauna mempunyai peranan untuk mendukung nilai keanekaragaman di setiap ketinggian. Nilai indeks perataan masih mengindikasikan bahwa pada ketinggian $750 \mathrm{~m}$ dpl, $980 \mathrm{~m}$ dpl dan 1100 $\mathrm{m}$ dpl persebaran mikroartropoda bryofauna terestrial cukup merata meskipun terdapat taksa yang dominan.

Berdasarkan data sekunder yang dikemukakan Ergiana (2013), ditemukan jenisjenis bryophytes yang merupakan habitat 
mikroartropoda bryofauna terrestrial di zona tropik Gunung Ungaranpada tiga ketinggian yang berbeda. Kelompok Brophyta (lumut daun) dan Marchantiophyta (lumut hati) merupakan bryophytes yang ditemukan di tiga stasiun yang secara umummembentuk habitus seperti pohon kecil sehingga bryofauna dapat memanfaatkan tumbuhan lumut sebagai habitatnya. Menurut Glime (2007), bryophyta dihuni mikroartropoda bryofauna lebih tinggi, karena kemampuannya untuk menahan air sangat baik yang menjadii faktor penting bagi kehidupan bryofauna, sehingga lumut tersebut terdapat lebih banyak bryofaunanya daripada lumut yang kurang mampu menahan air.

Marchantiophyta yang ditemukan secara umum tumbuh dan memiliki jumlah jenis terbesar di permukaan tanah (Goffinet \& Shaw 2009 dan Gradstein, 2011). Marchantiophyta ditemukan lebih banyak daripada bryophyta di ketinggian $1100 \mathrm{~m}$ dpl karena Marchantiophyta lebih mudah ditemukan di tempat yang basah dan lembab, akan tetapi keanekaragaman bryofauna pada Marchantiophyta cenderung lebih sedikit keanekaragaman taksanya, hal tersebut kemungkinan disebabkan karena Marchantiophyta umumnya tidak tahan terhadap kondisi kekeringan karena tidak mampu menahan air seperti bryophyta.

Ketinggian $750 \mathrm{~m}$ dpl terdapat lumut terestrial yang menunjukkan spesies yang paling beragam begitu juga keanekaragaman bryofauna merupakan yang tertinggi. Menurut Indrawan (2007), kelimpahan lumut terestrial yang bervariasi tergantung asosiasi dengan tumbuhan di sekitarnya. Ketinggian $750 \mathrm{~m}$ dpl merupakan kawasan hutan Wana Wiasata Gonoharjo yang vegetasinya cukup bervariasi sehingga tumbuh beragam lumut di kawasan ini.

Jenis tumbuhan lumut yang tumbuh di ketinggian $980 \mathrm{~m}$ dpl mengalami penurunan, hal tersebut kemungkinan karena merupakan kawasan hutan pinus, kawasan ini tidak terlalu beranekaragam vegetasi ekosistemnya. Kondisi vegetasi yang seragam dan intensitas cahaya matahari yang tinggi sehingga kondisi permukaan tanahnya cukup kering. Umumnya karakteristik tumbuhan lumut yang di temukan di ketinggian $980 \mathrm{~m}$ dpl yaitu berukuran kecil, batangnya tumbuh tegak, daunnya berwarna kuning kehijauan. Menurut Conard (1956), setiap jenis lumut mempunyai kemampuan beradaptasi dengan habitat ternaungi atau intensitas cahaya yang rendah. Kawasan ini hanya tempat-tempat tertentu saja yang dapat dijumpai adanya lumut, misalnya di permukaan batu dan tempat ternaungi.

Jenis lumut di ketinggian $1100 \mathrm{~m} \mathrm{dpl}$ cukup melimpah karena kelembaban di kawasan ini cukup menunjang untuk kehidupan lumut, sehingga banyak ditemukan jenis-jenis lumut Marchantiophyta yang hidup di tempat ini. Bryofaunanya juga paling melimpah jumlahnya, hal ini kemungkinan disebabkan karena tumbuhan lumut di lingkungan ini lebih tebal dan subur jika dibandingkan dengan ketinggian $750 \mathrm{~m}$ dpl dan $980 \mathrm{~m}$ dpl.

Hal tersebut sesuai dengan Bozanik (2011), ketebalan lumut pada ekosistem hutan merupakan faktor lingkungan yang berpengaruh pada distribusi dan kelimpahan bryofauna yang berasosiasi dengan tumbuhan lumut.

Faktor-faktor abiotik seperti suhu udara, di tiga stasiun penelitian rata-rata $26,73^{\circ} \mathrm{C}$, suhu tertinggi berada di ketinggian $750 \mathrm{~m}$ dpl dengan suhu $27,8^{\circ} \mathrm{C}$ di ketinggian $750 \mathrm{~m}$ dpl lebih panas karena merupakan kawasan hutan Wana Wisata Gonoharjo yang cenderung terbuka, sedangkan tumbuhan lumut pada umumnya hidup pada tempat yang lembab dengan suhu yang rendah. Suhu terendah berada di ketinggian $1100 \mathrm{~m}$ dpl dengan suhu $25,6^{\circ} \mathrm{C}$. Menurut BMKG (2012) temperatur udara pada bulan April menunjukkan kisaran $26,8^{\circ} \mathrm{C}$. Suhu udara cenderung menurun di tiap stasiun seiring dengan semakin tingginya tempat. Menurut Huston (1994), lingkungan dan topografi mempengaruhi sebaran organisme maupun kekayaan jenis di suatu tempat. Hal tersebut dapat dikatakan bahwa kelimpahan taksa di zona tropik Gunung Ungaran dipengaruhi oleh faktor lingkungan yang berperan penting dalam distribusi lumut maupun bryofauna.

Kelembaban udara merupakan faktor penting pendukung pertumbuhan lumut dan bryofauna. Umumnya lumut memerlukan kelembaban yang relatif tinggi untuk menunjang pertumbuhannya, sedang untuk bryofauna kelembaban sangat penting untuk menetralisir 
suhu tubuhnya dari penguapan. Hasil pengukuran kelembaban udara di kawasan Gunung Ungaran di zona tropik di ketinggian $750 \mathrm{~m}$ dpl sebesar $65 \%$ dan di ketinggian $980 \mathrm{~m}$ dpl dan $1100 \mathrm{~m} \mathrm{dpl}$ sebesar $60 \%$, bryofauna masih dapat tumbuh dengan baik di tempat tersebut. Menurut BMKG (2012), kelembaban udara pada bulan April menunjukkan kisaran $78 \%$.

Tabel 3. Data faktor lingkungan zona tropik Gunung Ungaran

\begin{tabular}{lcll} 
Faktor lingkungan & I & II & III \\
\hline Kelembaban udara $(\%)$ & 65 & 60 & 60 \\
Temperatur udara $\left({ }^{\circ} \mathrm{C}\right)$ & 27.8 & 26.5 & 25.6 \\
Intensitas Cahaya (lux) & 5290 & 3900 & 560 \\
\hline
\end{tabular}

Kelembaban di masing-masing ketinggian mempengaruhi pertumbuhan lumut serta kelimpahan dan keanekaragaman taksa bryofauna pada ketinggian yang berbeda, hal tersebut dapat disebabkan karena setiap individu memiliki batas toleransi untuk beradaptasi.

Kelembaban sangat bergantung dengan keadaan suhu, dan penyinaran matahari yang mempengaruhi laju penguapan air dalam tanah. Tanah yang semakin lembab maka semakin banyak tumbuhan lumut yang hidup di tempat tersebut dan semakin beranekargam bryofauna.

Hasil pengukuran intensitas cahaya di Gunung Ungaran pada zona tropik (Tabel 3.) cukup mendukung untuk pertumbuhan lumut dan bryofauna. Intensitas cahaya matahari akan mempengaruhi suhu udara, karena radiasi cahaya matahari menjadikan suhu menjadi meningkat. Intensitas cahaya tertinggi ada di ketinggian 750 $\mathrm{m}$ dpl dengan besar 5290 lux, di ketinggian 980 $\mathrm{m}$ dpl intensitas cahayanya sebesar 3600 lux dan intensitas cahaya terendah di keinggian $1100 \mathrm{~m}$ dpl sebesar 560 lux. Intensitas cahaya yang tinggi membuat suhu menjadi lebih panas, sehingga suhu udara di ketinggian $750 \mathrm{~m}$ dpl yaitu $27,8^{\circ} \mathrm{C}$ tingginya intensitas cahaya tersebut disebabkan karena kawasan ini merupakan kawasan hutan wisata yang terbuka dan lumut yang berada di kawasan ini cenderung lebih tipis.

Menurut Glime (2007), tumbuhan lumut pada kawasan zona tropik mampu hidup diatas suhu $25^{\circ}$ C. Bryofauna memanfaatkan lumut tempat untuk berlindung dari perubahan suhu secara ekstrim yang dapat mengganggu metabolismenya sehingga membutuhkan tempat yang lebih nyaman. Lumut yang mampu menyimpan air dan menyediakan kelembaban yang cukup untuk tempat hidup bryofauna. Menurut BMKG (2012), pada bulan April curah hujan 162-186 mm, dan suhu udara mencapai 26,7-26,8 $8^{\circ}$. Faktor lingkunganmengenai temperatur, curah hujan yang menjadi siklus tahunan serta karakteristik tanah, mempengaruhi struktur dan komunitas biologi setempat.Hasil pengukuran faktor-faktor lingkungan tersebut dapat dikatakan bahwa area penelitian merupakan kawasan yang masih mendukung pertumbuhan keanekaragaman mikroartropoda bryofauna terestrial.

\section{KESIMPULAN}

Kesimpulan dari penelitian ini adalah bahwa pada ketiga ketinggian yang berbeda taksa Mesostigmata dan Oribatida merupakan taksa yang dominan di semua ketinggian, kecuali pada ketinggian $980 \mathrm{~m}$ dpl Oribatida termasuk subdominan. Keanekaragaman mikroartropoda bryofauna terestrial pada ketinggian yang berbeda di zona tropik menunjukan pola keanekaragaman yang semakin menurun, seiring dengan semakin naiknya ketinggian tempat. Secara umum distribusi taksa mikroartropoda bryofauna terestrial pada ketinggian yang berbeda di zona tropik Gunung Ungaran cukup merata dengan nilai indeks perataan antara 0,84-0,94. Kekayaan taksa mikroartropoda bryofauna terestrial dan keanekaragaman jenis bryophytes pada ketinggian yang berbeda di zona tropik menunjukkan kesamaan pola yang bersifat fluktuatif.

\section{UCAPAN TERIMAKASIH}

Peneliti mengucapkan terima kasih kepada Tim Peneliti Hibah Bersaing tahun anggaran 2012 (Lilih Khotim Perwati, S.Si, M.Si, Rully Rahadian, S.Si.M.Si.Ph.D dan Karyadi Baskoro, S.Si.M.Si) 
dengan Surat Penugasan Pelaksanaan Penelitian Pengembangan Karya Ilmiah No : 117C 7/UN7.5/PG/2012 yang telah mengijinkan peneliti untuk mengikuti kegiatan penelitian, dengan judul Struktur Komunitas Mikroartropoda Bryofauna Terestrial di Zona Tropik Gunung Ungaran, Semarang, Jawa Tengah.

\section{DAFTAR PUSTAKA}

Andrew. N.R., L. Rodgerson, and M. Dunlop. 2003. Variation in Invertebrate Bryophyte Community Structure at Different Spatial Scales Along Atitudinal Gradient. J. Blogeorgr. 30: 731-746.

BMKG. 2012. Stasiun Klimatologi Semarang. Semarang. Indonesia.

Božanić, Bojana.2011. Terrestrial Mosses as Living Environment For Invertebrates.Thesis.Department of Ecology and Environmental Sciences.Faculty of Science.Palacky University,in Partial Fulfilment.

Ergiana, Heti. 2013. Keanekaragaman Bryoflora Zona Tropik Gunung Ungaran.Skripsi. Program Studi Biologi, FSM Universitas Diponegoro. Semarang.

Glime, M. 2007. Bryophyte Ecology. Vol. II. Bryological Interaction.Ebook sponsored by
Michigan Technological University and the International Association of Bryologists. http://www.bryoecol.mtu.edu/.1 5 Agustus 2012.

Gradstein, S.R. 2011. Guide to the Liverworts and Hornworts of Java. SEAMEO BIOTROP. Bogor.

Indrawan, Mochamad., Richard B. Primarc dan Jatma Supriatna. 2007. Biologi Konservasi. Edisi Revisi. Yayasan Obor Indonesia. Jakarta

Odum, E. P. 1993. Dasar-Dasar Ekologi.Cetakan 4.Alih Bahasa : Samingan T. dan Srigandono B. UGM Press, Yogyakarta.

Rahadian, R. 2009. Structure of Collembolla Community and Its Nutrient Mineralization as Affected by Applycation of Different Organic Manures and Effective Microorganisms.Thesis.University of the Philippinies Los Banos in Partial.

Southwood, T.R.E. 1982. The Guild Composition of Artrhopod Communities in Trees.Jurnal of Animal Ecology 54(1): 289-306.

Steenis, Van. C. G. G. J. 2006. Flora Pegunungan Jawa. LIPI, Bogor. 